\title{
Null Single Nucleotide Polymorphism in Chemokine Receptor 5 (CCR5) Genes among the Ijaw Ethnic Population of Nigeria
}

\section{Kenneth Onowosome Zifawei ${ }^{1}$, Opuada Stowe', Teddy Charles Adias' ${ }^{2}$, Mirabeau Youtchou Tatfeng2, Zaccheaus Awortu Jeremiah ${ }^{2}$}

\author{
${ }^{1}$ Department of Medical Laboratory Science, Rivers State University of Science and Technology, Port Harcourt, Nigeria \\ ${ }^{2}$ Department of Medical Laboratory Science, Niger Delta University, Wilberforce Island, Nigeria \\ Email: zacjerry39@gmail.com
}

How to cite this paper: Zifawei, K.O., Stowe, O., Adias, T.C., Tatfeng, M.Y. and Jeremiah, Z.A. (2016) Null Single Nucleotide Polymorphism in Chemokine Receptor 5 (CCR5) Genes among the Ijaw Ethnic Population of Nigeria. Open Journal of Blood Diseases, 6, 59-66.

http://dx.doi.org/10.4236/ojbd.2016.64009

Received: September 30, 2016

Accepted: November 14, 2016

Published: November 17, 2016

Copyright $\odot 2016$ by authors and Scientific Research Publishing Inc. This work is licensed under the Creative Commons Attribution International License (CC BY 4.0).

http://creativecommons.org/licenses/by/4.0/ (c) (i) Open Access

\section{Abstract}

Background: A deletion of $32 \mathrm{bp}$ in the nucleotide sequence of CCR5 gene results in a defective CCR5 which confers protection from HIV infection in the homozygous state, while reducing the rate of disease progression to AIDS and death in the heterozygous state. The status of the CCR $5 \Delta 32$ gene has not been reported in Nigeria. Aim: This study was aimed at analyzing single nucleotide polymorphism of CCR5 gene among the Ijaws resident in Yenagoa, Nigeria. Methods: 100 subjects (75 HIV negative and $25 \mathrm{HIV}$ positive control) were recruited for this study. The CCR5 genes were amplified by 2 Stage PCR reaction using GeneAmp 9700 PCR system utilizing specific primers that would flank $32 \mathrm{bp}$ deletion, followed by agarose gel electrophoresis, DNA sequencing of 20 subjects was done followed by phylogenetic and polymorphism analysis. Results: The results showed that 75 (100\%) of the HIV negative subjects had 189 base pair in their CCR5 gene. Nucleotide of the $20(100 \%)$ of the sequenced samples were conservatively same and no SNP was observed. Conclusion: This study documented no SNPs in CCR5 gene of the study population hence; the study population has no protection from HIV infection.

\section{Keywords}

CCR5, Single Nucleotide Polymorphism (SNP), PCR Amplicon

\section{Introduction}

Cystein-Cystein Chemokine Receptor 5 (CCR5) is a co-receptor for human immunodeficiency virus (HIV). It facilitates the virus entry into cells and mediates infection [1] [2]. CCR5 is expressed in memory or effect or $\mathrm{T}$ cells, monocytes or macrophages and 
immature dendritic cells [3]. It is important in physiological and pathological conditions because of its ability to bind chemokines and regulate the migration of leukocytes throughout the body [4].

In humans, CCR5 gene is situated in position 21 of the $\mathrm{p}$ arm of chromosome 3 and consists of four exons and two introns [5]. Two promoters have been reported in the gene, $\mathrm{P} 1$, an upstream promoter results in two full length transcript variants, while $\mathrm{P} 2$, a weak downstream promoter do not have exon 1 and results in many truncated transcripts, but give rise to same CCR5 protein [5] [6] [7].

A32-bp deletion in the Open Reading Frame (ORF) of the gene (CCR5 $\Delta 32)$, has been reported to result in a premature shut down of translation and this gives a non-functional receptor [8]. Research showed that, this non-functional CCR5 protein (CCR5 $\Delta 32$ ), protects from HIV infection in the homozygous state, while offering protection from infection or reducing the rate of progression of the disease to AIDS and death in the heterozygous state [9]. CCR2 is another chemokine receptor located close to the CCR5 gene region in chromosome 3 (Figure 1). A CCR2V64I (which reads, valine to isoleucine amino acid substitution at position 64 of CCR2) has been reported to be closely linked to certain single nucleotide polymorphisms (SNPs) in the CCR5cis-regulatory region [10] [11] [12].

CCR5 $\triangle 32$ alleles have been reported to have variable distributions along geographic lines. A frequency of $10 \%-20 \%$ among European populations, with the highest found in northern Europe, and a marked decrease from the European figure to $2 \%-5 \%$ in the Middle East and the Indian subcontinent and is rare (1\%) in populations of African origin [5] [13] [14] [15].

CCR5 has been documented as a co-receptor in HIV infection. A sequence deletion of this gene is believed to reduce the risk of HIV infection. However, this deletion is reported in a lower percentage of the African population. No study on the nucleotides sequence of this gene has been reported in Nigeria. This study was therefore conducted among the adult population in Yenagoa, Nigeria to bridge this knowledge gap.

\section{Materials and Methods}

\subsection{Study Design and Area}

A cross-sectional observational study design was used. The study was carried out in Yenagoa, Bayelsa, South Nigeria.

\subsection{Ethical Considerations}

Ethical clearance was sought and gotten from the Bayelsa State Ministry of Health Ethi-

\section{Chr 3}

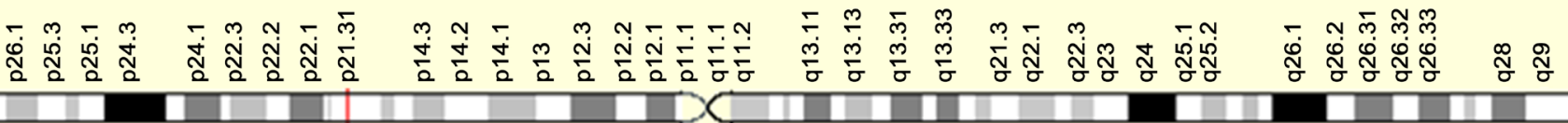

Figure 1. Chromosome 3 showing position 21 where CCR5 gene is located. 
cal Committee in line with Helsinki Declaration. Subjects were informed on the objectives, benefits and procedure of the study and they were reassured of confidentiality. Written Informed consent was obtained from each subject. The investigations were carried out at no cost to the subjects.

\section{Study Population}

Adult residents of Yenagoa within the ages of 19 to 30 years who attended Voluntary HIV Counselling and Testing Centre, HIV/STI Division, Department of Public Health, Bayelsa State Ministry of Health, Yenagoa. HIV negative subjects were used while, HIV positives subjects served as control.

\subsection{Sample Size}

The sample size was determined using W.G Cochran's method [16]; Sample size $=\mathrm{z}^{2} \times$ $\mathrm{p} \times \mathrm{q} / \mathrm{d}^{2}$ Where $\mathrm{p}=$ Prevalence in Africa which is $1 \% \mathrm{Q}=1-\mathrm{p}, \mathrm{z}=$ confidence level (z-score) at $95 \%$ is $1.96, d=$ acceptable $\mathrm{p}$-value given as 0.05 . Gives a sample size of 15 which is statically significant but, to expand the study scope 100 subjects was recruited while only 20 samples were sent for DNA sequencing and bioinformatics.

\subsection{Sample Collection}

Blood was collected aseptically from the median cubital vein of subjects into $4 \mathrm{ml}$ EDTA Vacuumtainer tubes using USAID/FHI360 method [17].

\subsection{Molecular Studies}

\section{DNA Extraction}

Genomic DNA was isolated from the EDTA anti-coagulated whole blood samples using Quick gDNA Mini Prep kits supplied by Zymos Research Inqaba, South Africa. Procedure for extraction was according to the manufacturer's Protocol on the extraction of gDNA from whole blood. Extracted DNAs were stored at $-20^{\circ} \mathrm{C}$ elsius until used.

\subsection{PCR Reaction Mixture}

A total of 100 polymerase chain reactions were performed in a $20 \mathrm{ul}$ PCR reaction mix as shown below;

Master $\operatorname{mix}=10.0 \mathrm{ul}$,

Forward Primer $=0.20 \mathrm{ul}$,

Reverse Primer $=0.20 \mathrm{ul}$,

Template $=3.0 \mathrm{ul}$,

PCR Water $=6.6 \mathrm{ul}$,

Total $=20 \mathrm{ul}$.

A portion of the CCR5 gene from gDNA was amplified by 2 Stage PCR reaction using GeneAmp 9700 PCR system utilizing primers that would flank the 32-bp deletion (P1(2975), 5'CAAAAAGAAGGTCTTCATTACACC-3' and P2(2976), 5'-CCTGTGCCTCTTCTTCTCATTTCG-3'. Steps of PCR were: 
1) Initial Denaturation,

2) Denaturation,

3) Annealing,

4) Extension.

Steps 2 to 4 were repeated in 5 cycles and 35 cycles for each DNA sample in stages 1 and 2 respectively.

\section{Agarose Gel Electrophoresis}

This was done on a portion of the CCR5 gene PCR amplicons. The 2.5\% agarose gel contained ethidium bromide $1 \mu \mathrm{g} / \mathrm{ml}$ as stain. A $10 \mu \mathrm{l}$ aliquot of each $20 \mu \mathrm{l}$ PCR reaction mixture ran on a $2.5 \%$ agarose gel alongside a GeneRuler DNA Ladder Mix (readyto-use; Thermo Fischer Scientific, Waltham, MA) to determine the lengths of the PCR products and the appropriately sized products was visualized under UV illuminator and the bands were micro-photographed.

\subsection{Sequencing}

The CCR5-PCR amplicons were sequenced using the Bigdye Terminator Kit on an ABI 3510 sequencer by Inqaba Biotechnological, Pretoria South Africa.

\subsection{Phylogenetic Analysis}

Sequences obtained were edited by the bioinformatics algorithm Trace edit, similar sequences were downloaded from the National Center for Biotechnology Information (NCBI) data base using BLASTN. These sequences were aligned using ClustalX. Evolutionary lineage was inferred using the Neighbour-Joining method [18] in MEGA 6.0. The bootstrap [19] consensus tree inferred from 500 replicates was taken to represent the evolutionary lineage of the taxa analyzed. The evolutionary distances were computed using the Jukes-Cantor method [20].

\section{Polymorphism Analysis}

The aligned sequences of the DNA fragment of the isolates were translated to protein sequences using the bioinformatics software MEGA 6.

\subsection{Results}

A total of 100 subjects, were recruited for the study, among them 75 (75\%) were HIV negative and 25 (25\%) were HIV positive controls. Sequencing was done for only 20 samples. The allelic frequencies of these genes were: $0 \%$ and $100 \%$ respectively for CCR5-Delta32 and CCR5 (Table 1).

Phylogenetic analysis of sequences obtained from the 20 CCR5 gene PCR amplicons when compared with similar sequences from the NCBI data base using BLASTN showed that subjects were homozygous for the CCR5 gene (Table 2). Sequences were aligned using ClustalX. Bioinformatics for polymorphism on the 20 CCR5 gene PCR amplicons using MEGA 6.0 showed no single nucleotide polymorphisms (SNPs) 
Table 1. Showing demography of study population.

\begin{tabular}{ccccc}
\hline Age Range in Years & No. & \% Male & \% Female & Group \% of Population \\
\hline $19-21$ & 31 & 25.8 & 74.2 & 31 \\
$22-24$ & 23 & 26.1 & 73.9 & 23 \\
$25-27$ & 21 & 19.0 & 81.0 & 21 \\
$28-30$ & 25 & 36.0 & 64.0 & 25 \\
\hline
\end{tabular}

Mean age 24.3 Male 27\% Female 73\%.

Table 2. Showing CCR5 distribution in the study population.

\begin{tabular}{ccccc}
\hline HIV Status & Number of Base Pairs & Homozygous CCR5 \% & $\begin{array}{c}\text { Homozygous } \\
\text { CCR5 } \Delta 32 \%\end{array}$ & $\begin{array}{c}\text { Heterozygous } \\
\text { CCR5 } \Delta 32 \%\end{array}$ \\
\hline Negative & 189 & 75 & 0 & 0 \\
Positive & 189 & 25 & 0 & 0 \\
\hline
\end{tabular}

among the 20 sequenced samples, since their protein sequences were conservatively the same (Table 3) when compared to standard CCR5 gene from NCBI. Gene.

Figure 2 shows the agarose gel electrophoresis of CCR5 gene PCR amplicons for the 75 HIV negative and 25 HIV positive subjects.

\section{Discussion}

In Nigeria, the HIV prevalence recorded in Bayelsa State in 2007 was ranked the third highest and thus became a flash point [21]. It therefore became necessary for deliberate research to be carried out to explain why this HIV prevalence could assume such an alarming proportion. It has been reported that a 32 base pair deletion (CCR5 $\Delta 32$ ) in the coding region is a non functional receptor that confers resistance to HIV and some degree of protection from HIV infection. [8] [9] and CCR5 is a co-receptor for human immunodeficiency virus (HIV) that mediates HIV infection [1] [2]. However, there is paucity of information relating to studies done on SNPs and the nucleotide sequences of this gene in Nigeria. Hence, this study was aimed at investigating SNPs of CCR5 gene if any, among the Ijaws of the Niger Delta region of Nigeria. .

Our study revealed that 75 (100\%) of the HIV negative subjects had 189 base pair in their CCR5 gene. The agarose gel electrophoresis of CCR5 gene PCR amplicons for the $75 \mathrm{HIV}$ negative and $25 \mathrm{HIV}$ positive subjects showed no genetic deletion on the CCR5 genes of the subjects, as it read 189bp for both the HIV negative subjects and HIV positive controls when compared with a Gene Ruler DNA Ladder Mix.

These results obtained in this study corroborate some earlier findings that CCR5 $\Delta 32$ confers some degree of protection from HIV. [6] [7] [8]. However, one study found SNP of CCR5 gene to be absent (0/268) in Central Africa [15].

In 1997, a man homozygous for CCR5 32 was found to be infected with HIV-1 after receiving several pints of infected blood. This finding was uncommon and exceptional and raised so much questions to the authenticity of CCR $5 \Delta 32$ homozygosity providing 
Table 3. Translated nucleotide sequences of the amplified CCR5 segment from the subjects.

\begin{tabular}{cl}
\hline Seq Name & \\
\hline 1_R5F_H10_22 & FWKNFQTLKI VILGLVLPLL VMVICYSGIL KTLLRCRNEK KRHR \\
2_R5F_A11_02 & FWKNFQTLKI VILGLVLPLL VMVICYSGIL KTLLRCRNEK KRHR \\
3_R5F_B11_05 & FWKNFQTLKI VILGLVLPLL VMVICYSGIL KTLLRCRNEK KRHR \\
5_R5-F_D05_11 & FWKNFQTLKI VILGLVLPLL VMVICYSGIL KTLLRCRNEK KRHR \\
7_R5-F_F05_17 & FWKNFQTLKI VILGLVLPLL VMVICYSGIL KTLLRCRNEK KRHR \\
8_R5-F_G05_20 & FWKNFQTLKI VILGLVLPLL VMVICYSGIL KTLLRCRNEK KRHR \\
9_R5-F_H05_23 & FWKNFQTLKI VILGLVLPLL VMVICYSGIL KTLLRCRNEK KRHR \\
10_R5-F_A06_03 & FWKNFQTLKI VILGLVLPLL VMVICYSGIL KTLLRCRNEK KRHR \\
11_R5-F_B06_06 & FWKNFQTLKI VILGLVLPLL VMVICYSGIL KTLLRCRNEK KRHR \\
12_R5-F_C06_09 & FWKNFQTLKI VILGLVLPLL VMVICYSGIL KTLLRCRNEK KRHR \\
13_R5-F_D06_12 & FWKNFQTLKI VILGLVLPLL VMVICYSGIL KTLLRCRNEK KRHR \\
14_R5-F_E06_15 & FWKNFQTLKI VILGLVLPLL VMVICYSGIL KTLLRCRNEK KRHR \\
15_R5-F_F06_18 & FWKNFQTLKI VILGLVLPLL VMVICYSGIL KTLLRCRNEK KRHR \\
16_R5-F_G06_21 & FWKNFQTLKI VILGLVLPLL VMVICYSGIL KTLLRCRNEK KRHR \\
17_R5-F_H06_24 & FWKNFQTLKI VILGLVLPLL VMVICYSGIL KTLLRCRNEK KRHR \\
18_R5-F_A07_01 & FWKNFQTLKI VILGLVLPLL VMVICYSGIL KTLLRCRNEK KRHR \\
19_R5-F_B07_04 & FWKNFQTLKI VILGLVLPLL VMVICYSGIL KTLLRCRNEK KRHR \\
20_R5-F_C07_07 & FWKNFQTLKI VILGLVLPLL VMVICYSGIL KTLLRCRNEK KRHR \\
\hline
\end{tabular}

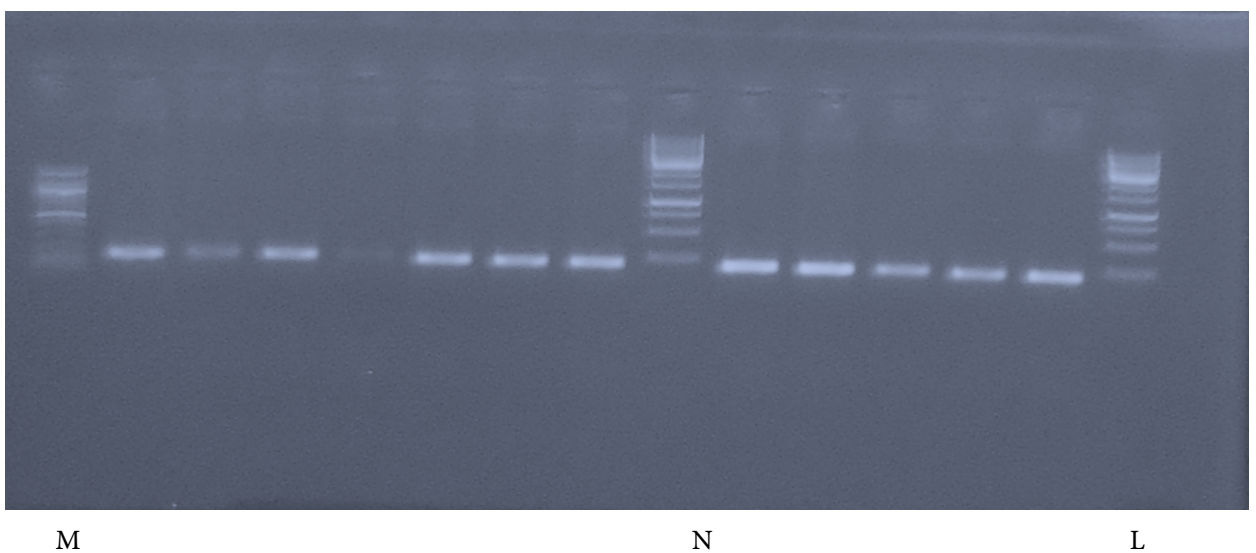

Figure 2. Photomicrograph of the agarose gel electrophoresis of the CCR5 gene (189bp). Lane 1 12 represent the CCR5 bands while $\mathrm{M}, \mathrm{N}$ and $\mathrm{L}$ represent $100 \mathrm{bp}, 1 \mathrm{~kb}$ and $1 \mathrm{~kb}$ ladder respectively.

strong relative resistance to parenterally acquired HIV-1 infection [22]. However, in this exceptional case, it was thought that the subject might have been infected with HIV-1 strain that can use an alternative receptor.

The results of periodic national surveys among ante-natal clinic attendees in Nigeria 
has shown a progressive decrease in the adult HIV sero-prevalence rate from $6.5 \%$ in 2007 [21] to $2.7 \%$ in 2012 [23]. This low prevalence could be as a result of concerted HIV education from both the State Ministry of Health and non-governmental agencies in the fight against HIV/AIDS in the State. In fact, the prevalence rate of $2.7 \%$ in Bayelsa State as it is now is far lower than the National prevalence of 3.4\% [23]. It could be deduced that the large health sector response, and now a multi-sectoral response that focuses on prevention, treatment and mitigation of impact interventions has paid off in reducing the HIV prevalence. Such efforts need to be sustained especially in regions like this where there is nothing in our genetic makeup that confers resistance to the dreaded HIV infection.

\section{Conclusion}

We concluded that the nucleotide sequences of CCR5 gene are highly conserved and are all homozygous among HIV negative individuals living in this part of the globe. Hence, no protection is guaranteed if exposed to HIV CCR5 tropic strain. In other words, infection of such individuals with HIV predisposes them to rapid progression towards AIDS.

\section{References}

[1] Littman, D.R. (1998) Chemokine Receptors: Keys to AIDS Pathogenesis? Cell, 93, 677-680. http://dx.doi.org/10.1016/S0092-8674(00)81429-4

[2] Mummidi, S., Ahuja, S.S., Gonzalez, E., Anderson, S.A., Santiago, E.N., Stephan, K.T., Craig, F.E., O'Connell, P., Tryon, V. and Clark, R.A. (1998) Genealogy of the CCR5 Locus and Chemokine System Gene Variants Associated with Altered Rates of HIV-1 Disease Progression. Nature Medicine, 4, 786-793. http://dx.doi.org/10.1038/nm0798-786

[3] Oppermann, M. (2004) Chemokine Receptor CCR5: Insights into Structure, Function, and Regulation. Cell Signal, 16, 1201-1210. http://dx.doi.org/10.1016/j.cellsig.2004.04.007

[4] Guergnon, J. and Combadière, C. (2012) Role of Chemokines Polymorphisms in Diseases. Immunology Letters, 145, 15-22. http://dx.doi.org/10.1016/j.imlet.2012.04.010

[5] Novembre, J., Galvani, A.P. and Slatkin, M. (2005) The Geographic Spread of the CCR5 Delta32 HIV-Resistance Allele. PLoS Biology, 3, e339.

http://dx.doi.org/10.1371/journal.pbio.0030339

[6] Mummidi, S., Bamshad, M., Ahuja, S.S., Gonzalez, E., Feuillet, P.M., Begum, K., Galvis, M.C., Kostecki, V., Valente, A.J. and Murthy, K.K. (2000) Evolution of Human and NonHuman Primate CC Chemokine Receptor 5 Gene and mRNA. Potential Role for Haplotype and mRNA Diversity, Differential Haplotype Specific Transcriptional Activity, and Altered Transcription Factor Binding to Polymorphic Nucleotides in the Pathogenesis of HIV-1 and Simian Immunodeficiency Virus. Journal of Biology Chemistry, 275, 18946-18961. http://dx.doi.org/10.1074/jbc.M000169200

[7] Wierda, R. and van den Elsen, P. (2012) Genetic and Epigenetic Regulation of CCR5 Transcription. Biology, 1, 869-879. http://dx.doi.org/10.3390/biology1030869

[8] Dean, M., Carrington, M., Winkler, C., Huttley, G.A., Smith, M.W. and Allikmets, R. (1996) Genetic Restriction of HIV-1 Infection and Progression to AIDS by a Deletion Allele of the CKR5 Structural Gene. Hemophilia Growth and Development Study, Multicenter AIDS Cohort Study, Multicenter Hemophilia Cohort Study, San Francisco City Cohort, a Live 
Study. Science, 273, 1856-1862. http://dx.doi.org/10.1126/science.273.5283.1856

[9] Hayes, V.M., Petersen, D.C., Scriba, T.J., Zeier, M., Grimwood, A. and van Rensburg, E. (2002) African-Based CCR5 Single Nucleotide Polymorphism Associated with HIV-1 Disease Progression. AIDS, 16, 2229-2231. http://dx.doi.org/10.1097/00002030-200211080-00019

[10] Al-Abdulhadi, S.A. and Al-Rabia, M.W. (2010) Linkage and Haplotype Analysis for Chemokine Receptors Clustered on Chromosome 3p21.3 and Transmitted in Family Pedigrees with Asthma and Atopy. Annals Saudi Medicine, 30, 115-122. http://dx.doi.org/10.4103/0256-4947.60516

[11] Kostrikis, L.G., Huang, Y., Moore J,P., Wolinsky, S.M., Zhang, L., Guo, Y., Deutsch, L., Phair, J., Neumann, A.U. and Ho, D.D. (1998) A Chemokine Receptor CCR2 Allele Delays HIV-1 Disease Progression and Is Associated with a CCR5 Promoter Mutation. Nature Medicine, 4, 350-353. http://dx.doi.org/10.1038/nm0398-350

[12] Wichukchinda, N., Nakayama, E.E., Rojanawiwat, A., Pathipvanich, P., Auwanit, W., Vongsheree, S., Ariyoshi, K., Sawanpanyalert, P. and Shioda, T. (2008) Effects of CCR2 and CCR Polymorphisms on HIV-1 Infection in Thai Females. Journal of Acquired Immune Deficiency Syndrome, 47, 293-297. http://dx.doi.org/10.1097/QAI.0b013e318162caab

[13] Martinson, J.J., Chapman, N.H., Rees, D.C., Liu, Y.T. and Clegg, J.B. (1997) Global Distribution of the CCR5 Gene 32-Basepair Deletion. Nature Genetics, 16, 100-103. http://dx.doi.org/10.1038/ng0597-100

[14] Su, B., Sun, G., Lu, D., Xiao, J., Hu, F., Chakraborty, R., Deka, R. and Jin, L. (2000) Distribution of Three HIV-1 Resistance-Conferring Polymorphisms (SDF1-3'A, CCR2-641, and CCR5-Delta32) in Global Populations. European Journal Human Genetics, 8, 975-979. http://dx.doi.org/10.1038/sj.ejhg.5200568

[15] de Silva, E. and Stumpf, M.P. (2004) HIV and the CCR5-Delta32 Resistance Allele. Microbiology Letters, 241, 1-12. http://dx.doi.org/10.1016/j.femsle.2004.09.040

[16] Cochran, W.G. (1963) Sampling Techniques. 2nd Edition, John Wiley and Sons, New York.

[17] USAID/Fhi 360 Blood Collection Training: Adult Phlebotomy-300513 Modified 22 ${ }^{\text {nd }}$ October, 2013.

[18] Saitou, N. and Nei, M. (1987) The Neighbor-Joining Method: A New Method for Reconstructing Phylogenetic Trees. Molecular Biology and Evolution, 4, 406-425.

[19] Felsenstein, J. (1985) Confidence Limits on Phylogenies: An Approach Using the Bootstrap. Evolution, 39, 783-791. http://dx.doi.org/10.2307/2408678

[20] Jukes, T.H. and Cantor, C.R. (1969) Evolution of Protein Molecules. In: Munro, H.N., Ed., Mammalian Protein Metabolism, Academic Press, New York, 21-132. http://dx.doi.org/10.1016/B978-1-4832-3211-9.50009-7

[21] Federal Ministry of Health: National AIDS Spending Assessment for the Period 2007-2008; HIV Prevalence by States (2008) 4.

[22] O’Brien, T.R., Winkler, C., Dean, M., Nelson, J.A.E., Carrington, M., Michael, N.L. and White II, G.C. (1997) HIV-1 Infection in a Man Homozygous for CCR5 $\Delta 32$. Lancet, 348, 1219. http://dx.doi.org/10.1016/S0140-6736(97)24017-1

[23] Federal Ministry of Health: National HIV\&AIDS Reproductive Health Survey (NARHS PLUS ii 2012) Prevalence of HIV by State and Sex, 355. 
Submit or recommend next manuscript to SCIRP and we will provide best service for you:

Accepting pre-submission inquiries through Email, Facebook, LinkedIn, Twitter, etc. A wide selection of journals (inclusive of 9 subjects, more than 200 journals)

Providing 24-hour high-quality service

User-friendly online submission system

Fair and swift peer-review system

Efficient typesetting and proofreading procedure

Display of the result of downloads and visits, as well as the number of cited articles

Maximum dissemination of your research work

Submit your manuscript at: http://papersubmission.scirp.org/

Or contact ojbd@scirp.org 